\title{
Lack of good correlation of serum CC-chemokine levels with human immunodeficiency virus-1 disease stage and response to treatment
}

\author{
PING YE, POWEL KAZANJIAN, STEVEN L. KUNKEL, and DENISE E. KIRSCHNER
}

ANN ARBOR, MICHIGAN

\begin{abstract}
Three CC-chemokines-MIP-1 $\alpha$ (CCL3), MIP-1 $\beta$ (CCL4), and RANTES (CCL5)-are natural ligands for the human immunodeficiency virus-1 (HIV-1) coreceptor CCR5. To determine correlations between CC-chemokines and HIV-1 disease stage or response to treatment, we examined serum levels of MIP-1 $\alpha$, MIP-1 $\beta$, and RANTES in 60 infected patients during 18 months while they were taking highly active antiretroviral therapy (HAART). Our results demonstrate that serum levels of MIP- $1 \alpha$ and RANTES were increased in HIV-1-infected individuals compared with those in healthy controls. We found no significant differences among 4 clinical stages of HIV-1 infection in the serum levels of three CC-chemokines. Longitudinal HAART analyses revealed a pronounced decline in serum MIP- $1 \alpha$ levels over time. We found no difference in this decline between HAART responders and nonresponders. These findings indicate that production of MIP- $1 \alpha$ and RANTES changes during HIV-1 infection and treatment; however, our results suggest that serum levels of $\mathrm{CC}$ chemokines should not be used as biomarkers for HIV-1 disease stage or response to treatment. (J Lab Clin Med 2004;143:310-9)
\end{abstract}

\begin{abstract}
Abbreviations: ELISA = enzyme-linked immunosorbent assay; HAART = highly active antiretroviral therapy; $I^{+}=$HAART immunological responder; PBMC = peripheral-blood mononuclear cell; $\mathrm{VR}^{+}=$HAART virologic responder
\end{abstract}

E fficient entry of HIV-1 into target cells relies not only on CD4 molecules but also on chemokine receptors. Two chemokine receptors, CCR5 and CXCR4, act as the major coreceptors for HIV-1 and determine cellular tropism for different HIV-1 strains. ${ }^{1-4}$ The entry of R5 (non-syncytium-inducing) and X4 (syncytium-inducing) HIV-1 strains is mediated by coreceptors CCR5 and CXCR4, respectively. The critical role of chemokine receptors in HIV-1 transmis-

From the Departments of Microbiology and Immunology, Internal Medicine, and Pathology, University of Michigan Medical School.

Supported by National Institutes of Health grant HL62119 to Dr Kirschner and by the University of Michigan Rackham Predoctoral Fellowship, awarded to Dr Ye.

Submitted for publication July 21, 2003; revision submitted January 22, 2004; accepted January 22, 2004.

Reprint requests: Denise E. Kirschner, PhD, Department of Microbiology and Immunology, University of Michigan Medical School, Ann Arbor, MI 48109-0620; e-mail: kirschne@umich.edu.

(C) 2004 Elsevier Inc. All rights reserved.

$0022-2143 / \$$ - see front matter

doi:10.1016/j.lab.2004.01.012 sion and pathogenesis is exemplified by the protective role of a 32-nucleotide deletion of the receptor CCR5 in HIV-1 infection. ${ }^{5,6}$

Chemokines are chemotactic cytokines that attract leukocytes to the site of inflammatory reaction. ${ }^{7}$ They have received great attention for their role in HIV-1 infection, for example, by binding with chemokine receptors, thus competing with HIV-1 to inhibit infection. ${ }^{8}$ Three CC-chemokines-MIP-1 $\alpha$ (CCL3), MIP-1 $\beta$ (CCL4), and RANTES (CCL5)_bind to CCR5, whereas 1 CXC-chemokine, SDF-1, binds to CXCR4. ${ }^{1-4}$ The results of in vitro experiments suggest that MIP- $1 \alpha$, MIP- $1 \beta$ and RANTES are able to inhibit R5 HIV-1 infection of CD4 ${ }^{+}$T-cells, PBMCs, macrophages, and dendritic cells. ${ }^{8-11}$ Similarly, SDF-1 prevents infection by $\mathrm{X} 4$ strains. $^{3,4}$

Macrophages, $\mathrm{CD}^{+}$and $\mathrm{CD} 8^{+} \mathrm{T}$-cells, and naturalkiller cells are major cellular sources of MIP- $1 \alpha$, MIP$1 \beta$, and RANTES. ${ }^{12-16}$ During HIV-1 infection, these cells can be activated or infected or die, inducing altered secretion patterns of these 3 CC-chemokines. Besides binding to CCR5, MIP- $1 \alpha$ binds to CCR1 and 
CCR3, and RANTES binds to CCR1, CCR3, and CCR4. ${ }^{7}$ The ability of 1 chemokine to interact with multiple chemokine receptors may result in the activation of different intracellular signaling pathways.

Although CC-chemokines and their receptors seem to be relevant to the pathogenesis of HIV-1 infection, their exact role in disease progression in vivo has not been established. Several hypotheses exist to explain the dichotomous effects of CC-chemokines on HIV-1 infection. First, CC-chemokines bind to CCR5, competing with R5 HIV-1 by binding to the same receptor and thereby blocking viral entry. ${ }^{8-11}$ Second, CC-chemokines down-regulate the expression of their receptor, CCR5, from the host-cell surface. ${ }^{17,18}$ These 2 events may aid the selection of X4 strains over R5 strains during HIV-1 infection. Third, CC-chemokines induce an inflammatory response, attracting noninfected target cells to the site of active viral replication. ${ }^{19}$ Fourth, it is also likely that CC-chemokines induce intracellular signaling that enhances HIV-1 replication. ${ }^{20,21}$

Measurements of $\mathrm{CC}$-chemokines have been performed both from serum and from secretion by stimulated cells. The authors of several studies have tried linking CC-chemokine levels with HIV-1 disease progression or viral replication; however results have been contradictory. Some studies have revealed that progressors have a pronounced decline of CC-chemokines in serum, ${ }^{12}$ some have suggested that increased serum levels of RANTES and MIP- $1 \alpha$ are associated with disease progression, ${ }^{22,23}$ and still others have indicated that plasma levels of CC-chemokines have no correlation with disease progression or viral burden. ${ }^{24-26}$ Some suggest that augmented production of CC-chemokines limits viral replication, ${ }^{13,27}$ whereas others show no correlation between CC-chemokines and viral load. ${ }^{24,28}$

HAART greatly suppresses HIV-1 replication and increases $\mathrm{CD}^{+}{ }^{+}$T-cell counts in most but not all patients. ${ }^{29}$ However, the effects of HAART on the production of $\mathrm{CC}$-chemokines remain unclear. Increased, ${ }^{12,30-32}$ decreased, ${ }^{33}$ and unchanged ${ }^{30,33,34}$ levels of circulating and inducible CC-chemokines have been observed during treatment. Therefore, how serum CC-chemokines respond during HAART has not yet been characterized.

It is likely that the relationships between CC-chemokines and HIV-1 are far more complex than the initially proposed competition for binding to their common chemokine receptors. ${ }^{8}$ To this end, we conducted a longitudinal study to monitor serum levels of MIP- $1 \alpha$, MIP$1 \beta$, and RANTES in $60 \mathrm{HIV}-1$ infected patients during 18 months of continuous HAART. Our goal was to elucidate whether these $3 \mathrm{CC}$-chemokines are associated with HIV-1 disease stage or response to therapy.

\section{METHODS}

Patients and controls. We have approximately 800 patients in our HIV/acquired immunodeficiency syndrome clinic. Sixty HIV-1 infected patients were included in our study between January 1999 and March 2001. Candidates for inclusion were drug-naïve patients initiating HAART or drugexperienced patients in whom HAART failed and who were then switched to a salvage or rescue regimen. Of the 60 study subjects, 47 were men. The median age of this study group at the time of entry was 32 years (range 19-64 years). Thirty-five were white, 21 black, and 4 Hispanic. Sixteen opportunistic infections were detected in 27 of the 60 patients at baseline, including candidiasis, Pneumocystis carinii pneumonia, cytomegalovirus infection, and tuberculosis. Thirteen healthy individuals ( 8 men; median age 30 years, range $21-42$ years) were selected as negative controls for the HIV-1 patients.

The guidelines for when to initiate HAART were in flux throughout the study period. For this reason, patients enrolled in the study received HAART at an earlier stage of infection than they would have under current recommendations $\left(\mathrm{CD} 4^{+}\right.$ T-cells $350 / \mathrm{mm}^{3}$ of blood or HIV-1 RNA level 55,000 copies $/ \mathrm{mL} \mathrm{blood}^{35}$ ). Fifty-five patients started or switched to HAART after their initial clinic visits. Among these 55 patients, 25 were antiretroviral-naïve, whereas in the remaining 30 anti-retroviral therapy had failed before ( 26 were protease inhibitor experienced and 4 were reverse transcriptase inhibitor experienced) and were changed to a salvage HAART regimen on entering our study. HAART was continued for an average of 18 months in these patients (range 1-26 months). Five patients were not taking medication during our study (1 was antiretroviral-naïve; the other 4 had previously received protease-inhibitor therapy).

This research was performed in accordance with the principles of the Declaration of Helsinki. Fully informed consent was obtained from all subjects before initiation of the study. The experimental protocol was approved by the University of Michigan Institutional Review Board for Approval of Research Involving Human Subjects.

Sample collection. Blood was collected during each patient's initial clinic visit, before the initiation or switch of treatment and during subsequent clinic visits: 1 to 2 months after the initial visit and at 2- to 4-month intervals thereafter for as long as 2 years. Patients who were not taking medication were on a blood-draw schedule similar to that instituted for patients taking HAART. We collected 381 samples from these $60 \mathrm{HIV}-1$-infected patients $(6.4$ time-series samples per patient, on average). The number of serum samples per patient ranged from 2 to 8 . Thirteen healthy individuals donated blood once for controls.

We obtained serum samples by centrifuging coagulated blood, then stored them at $-80^{\circ} \mathrm{C}$ with $0.2 \%$ Triton $\mathrm{X}-100$ (Sigma Chemical Co, St Louis, Mo) for future determination of CC-chemokine levels.

Laboratory measurements. We determined HIV-1 viral load with the use of quantitative polymerase chain reaction (Amplicor Monitor; Roche Molecular Systems, Pleasanton, 
Table I. Immune and viral characterization of $60 \mathrm{HIV}-1$ infected patients

\begin{tabular}{|c|c|c|c|c|c|c|c|}
\hline \multirow[b]{2}{*}{ Group } & \multirow[b]{2}{*}{$n$} & \multicolumn{3}{|c|}{ Median (range) at baseline } & \multicolumn{3}{|c|}{ Median (range) at end } \\
\hline & & $\mathrm{CD4}^{+}$ & $\mathrm{CD}^{+}$ & HIV-1 & $\mathrm{CD}^{+}$ & $\mathrm{CD}^{+}$ & HIV-1 \\
\hline HAART naïve & 25 & $157(6-693)^{\star}$ & $563(98-2029)^{\star}$ & $4.9(1.7-5.9)$ & $389(21-1070)^{\dagger}$ & $692(391-1802)$ & $1.7(1.7-5.9)^{\dagger}$ \\
\hline HAART salvage & 30 & $319.5(1-1013)$ & $898(137-2149)$ & $4.5(1.7-5.9)$ & $306(1-1191)$ & $756(210-1849)^{\dagger}$ & $3.6(1.7-5.9)^{\dagger}$ \\
\hline No treatment & 5 & $722(365-1181)$ & $831(772-1879)$ & $3.5(1.7-5.1)$ & $70(418-1147)$ & 795 (579-1402) & $3.5(1.7-3.7)$ \\
\hline
\end{tabular}

${ }^{*} P<.05$ vs other 2 groups at same time point (Kruskal-Wallis test).

${ }^{\dagger} P<.05$ baseline values for same group (Wilcoxon signed-rank test).

Calif) with a detection limit of 50 RNA copies/mL of blood. Absolute $\mathrm{CD}^{+}$and $\mathrm{CD}^{+}$lymphocyte counts were measured with the use of standard flow-cytometric analysis.

A sandwich ELISA was used to assess serum levels of MIP- $1 \alpha$, MIP- $1 \beta$, and RANTES. The detection limit for this assay was $50 \mathrm{pg} / \mathrm{mL}$ for all $3 \mathrm{CC}$-chemokines. Each sample was measured in duplicate for each ELISA to ensure accuracy. We coated 96-well plates with monoclonal antibody (R\&D Systems, Minneapolis, Minn). Plates were then blocked with $2 \%$ bovine serum albumin. Serum was added to each well (1:50 dilution for detection of RANTES, no dilution for MIP- $1 \alpha$ and MIP-1 $\beta$ ) and incubated for 1 hour at $37^{\circ} \mathrm{C}$. After washing, biotinylated antibody (R\&D Systems) was added to the plates. After a 45 -minute incubation at $37^{\circ} \mathrm{C}$, avidin horseradish peroxidase was added. Finally, peroxidase substrate was added to the plates, which were incubated at room temperature. After terminating the reaction, we read the plates at $490 \mathrm{~nm}$ in an ELISA reader. For each assay, we constructed a standard curve using recombinant human MIP$1 \alpha /$ CCL3, MIP- $1 \beta /$ CCL4, or RANTES/CCL5 (R\&D Systems).

Statistical analysis. Detection levels of HIV-1 RNA copies, MIP- $1 \alpha$, and RANTES were entered if ELISA results appeared to be below the detection limit. Viral load was log-transformed before statistical analysis. We analyzed data using the SAS System for Windows, version 8 (SAS Institute, Cary, NC). The Wilcoxon rank-sum test was used for 2-group comparison, and the Kruskal-Wallis test was employed for comparisons involving more than 2 groups. We used the Wilcoxon signed-rank test to compare the same group at different time points. The associations between variables were assessed with the Spearman rank-order correlation. The $\chi^{2}$ test was applied in comparisons of rates of opportunistic infection between 2 groups. We considered $P$ values of less than .05 statistically significant.

\section{RESULTS}

Basic characterization of patients. The immune and viral characteristics of the $60 \mathrm{HIV}-1$-infected patients recruited to this study are shown in Table I. Patients were grouped according to treatment status. The 25 subjects who were treatment-naïve and were started on HAART at the beginning of this study demonstrated significant increases in their $\mathrm{CD}^{+} \mathrm{T}$-cell counts and significant decreases in viral load from their baseline
Table II. Response to treatment of 60 HIV-1-infected patients

\begin{tabular}{lrcccc}
\hline Group & $\boldsymbol{n}$ & $\mathbf{V R}^{+} / \mathbf{I} \mathbf{R}^{+}$ & $\mathbf{V R}^{+} / \mathbf{I R}$ & $\mathbf{V R}^{-} / \mathbf{I} \mathbf{R}^{+}$ & $\mathbf{V R}^{-} / \mathbf{I R}^{-}$ \\
\hline HAART naïve & 25 & 21 & 0 & 2 & 2 \\
HAART salvage & 30 & 10 & 4 & 4 & 12 \\
No treatment & 5 & $\mathrm{NA}$ & $\mathrm{NA}$ & $\mathrm{NA}$ & $\mathrm{NA}$ \\
\hline
\end{tabular}

$N A=$ not applicable

values to their endpoint values. This was expected; HAART is effective in drug-naïve patients. HAART salvage in previously treated patients induced a decrease in $\mathrm{CD}^{+}$T-cell counts and viral load during our study. The 5 patients who were not taking medication were characterized by consistent levels of $\mathrm{CD}^{+}$and $\mathrm{CD}^{+} \mathrm{T}$-cell counts and viral load over the entire study (Table I).

We defined a $\mathrm{VR}^{+}$as any patient who demonstrated a reduction in plasma viral load of more than $1.5 \mathrm{log}$ from the baseline value or maintained an undetectable viral load (50 copies/mL). We defined an $\mathrm{IR}^{+}$as any patient with an increase in $\mathrm{CD}^{+}{ }^{+} \mathrm{T}$-cell level of $10 \%$ at the end of study compared with the pretreatment value. ${ }^{36}$ The numbers of HAART responders $\left(\mathrm{VR}^{+} / \mathrm{IR}^{+}\right)$, discordant responders $\left(\mathrm{VR}^{+} / \mathrm{IR}^{-}\right.$, or $\left.\mathrm{VR}^{-} / \mathrm{IR}^{+}\right)$, and nonresponders $\left(\mathrm{VR}^{-} / \mathrm{IR}^{-}\right)$are listed in Table II by treatment status. Dividing patients according to treatment, we found that the failure rate of HAART for salvage regimens was 5 times of that for initial HAART regimens given to drug-naïve patients ( 12 of 30 vs 2 of 25).

Patients with opportunistic infections were characterized by significantly lower $\mathrm{CD}^{+}$and $\mathrm{CD}^{+}{ }^{+}$T-cell counts compared with no opportunistic infection $(P<$ $.05)$. This was expected because the risk of opportunistic disease was substantial when $\mathrm{CD} 4^{+}$T-cell counts reached a critically low level. The rates of opportunistic infection between HAART responders and nonresponders were not significantly different $(P>.05)$; neither were the rates between HAART-naïve and HAART-salvage patients $(P>.05)$. 
A
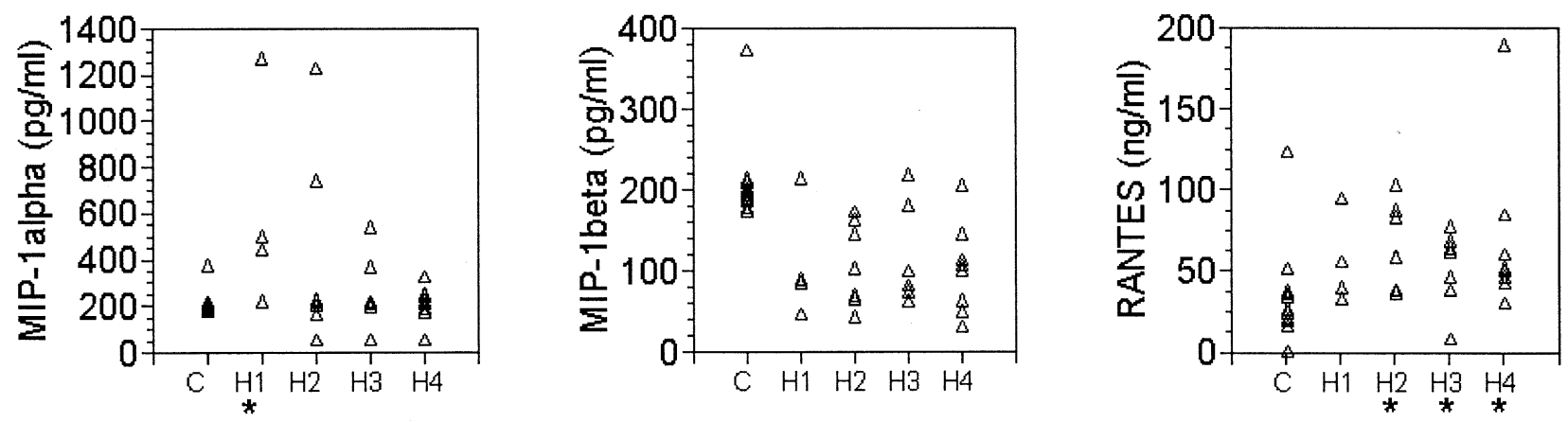

B

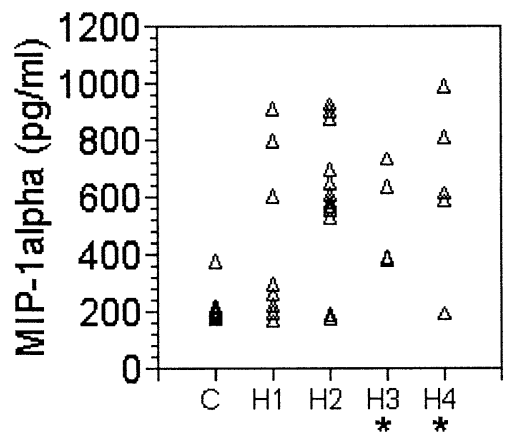

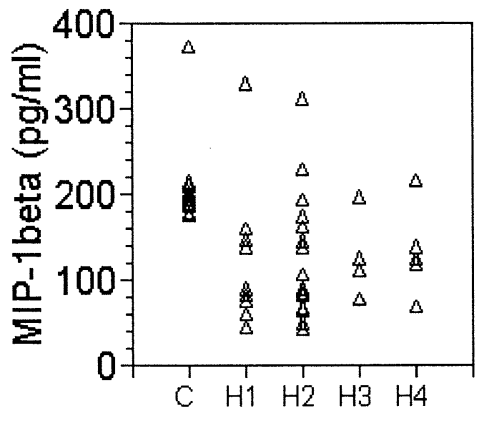

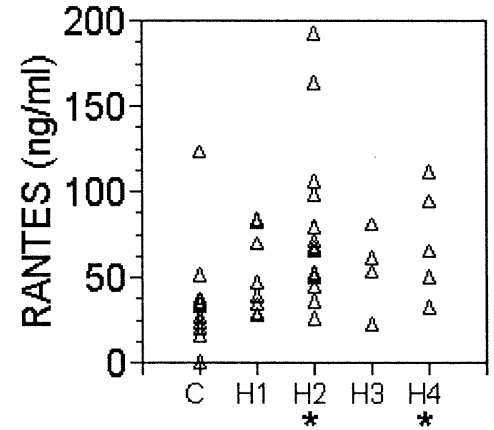

Fig 1. Relationship between CC-chemokines and HIV-1 disease stage. HIV-1 patients were grouped into 4 categories (represented by $\mathrm{H} 1, \mathrm{H} 2, \mathrm{H3}$, and $\mathrm{H4}$ ) according to $\mathrm{CD} 4^{+}$T-cell count/mm $\mathrm{mm}^{3}$ of blood. ${ }^{37} \mathrm{Healthy}$ controls are denoted by $C$. Each individual is denoted by a triangle. ${ }^{*} P<.05$, healthy controls vs each category of HIV-1 patients (Wilcoxon rank-sum test); the absence of an asterisk represents a $P$ value greater than .05 . We used the Kruskal-Wallis test to compare the 4 HIV-1 categories. A, HAART naïve patients; B, HAART-salvage patients.

Effects of sex, age, race, and opportunistic infection on CC-chemokine levels. Before exploring the relationship between serum CC-chemokine levels and disease progression or response to treatment, we tested whether other factors-sex, age, race, and opportunistic infection-would influence serum CC-chemokine levels. Baseline CC-chemokine values were used in these analyses.

Our data indicated that men had higher serum levels of all 3 CC-chemokines than did women, although not significantly $(P>.05$; data not shown). Grouping patients according to age distribution, we saw that age did not correlate with $\mathrm{CC}$-chemokine levels $(P>.05$; data not shown). Different racial groups, including white, black, and Hispanic subjects, exhibited comparable distributions of serum CC-chemokine levels $(P>.05$; data not shown). Similarly, opportunistic infection was not an influencing factor for CC-chemokine levels in HIV-1-infected patients $(P>.05$; data not shown). These trends held true in healthy controls - sex, age, and race did not affect $\mathrm{CC}$-chemokine levels (data not shown). Our findings suggested that these 4 factors did not contribute to variations in serum CC-chemokine levels; thus we were able to explore the correlation between CC-chemokines and HIV-1 disease stage or response to treatment.

CC-chemokine levels in relation to HIV-1 disease status. To study whether CC-chemokine levels in the serum are related to HIV-1 disease stage, we first classified 60 patients into HAART naïve and HAARTsalvage groups, then divided each group into 4 clinical stages according to baseline CD ${ }^{+}$T-cell count (Fig 1 ). The $4 \mathrm{CD}^{+}{ }^{+} \mathrm{T}$-cell categories were defined as greater than or equal to 500 cells $/ \mathrm{mm}^{3}$ of blood, 200 to 499 cells $/ \mathrm{mm}^{3}$ of blood, 50 to 199 cells $/ \mathrm{mm}^{3}$ blood, and less than 50 cells $/ \mathrm{mm}^{3}$ of blood. ${ }^{37}$

MIP- $1 \alpha$ levels in 1 category of HAART naïve patients and 2 categories of HAART-salvage patients were significantly increased compared with those in healthy controls $(P<.05)$. Similarly, RANTES levels in 3 naïve-patient categories and 2 salvage-patient categories were higher than those in controls $(P<.05)$. 
Table III. Correlation coefficients between CC-chemokines and immune/viral markers at baseline

\begin{tabular}{|c|c|c|c|c|c|c|}
\hline & $\mathrm{CD}^{+}(n)$ & $\mathrm{CD}^{+}(n)$ & HIV-1 (n) & $\operatorname{MIP}-1 \alpha(n)$ & MIP-1 $\beta(n)$ & RANTES $(n)$ \\
\hline $\mathrm{CD}^{+}{ }^{+}$ & $1.0(60)$ & $0.59^{\star}(53)$ & $-0.47^{\star}(60)$ & $0.17(60)$ & $-0.02(60)$ & $-0.10(60)$ \\
\hline $\mathrm{CD}^{+}$ & - & $1.0(53)$ & $-0.33^{*}(53)$ & $0.35^{\star}(53)$ & 0.09 (53) & 0.14 (53) \\
\hline HIV-1 & - & - & $1.0(60)$ & $-0.07(60)$ & $-0.22(60)$ & $0.00(60)$ \\
\hline $\mathrm{MIP}-1 \alpha$ & - & - & - & $1.0(60)$ & $0.41^{*}(60)$ & $0.07(60)$ \\
\hline MIP-1 $\beta$ & - & - & - & - & $1.0(60)$ & $0.13(60)$ \\
\hline RANTES & - & - & - & - & - & $1.0(60)$ \\
\hline
\end{tabular}

${ }^{*} P<.05$.

MIP-1 $\beta$ levels in 4 categories of HIV-1-infected patients, however, were similar to the control level in both HAART-naïve and salvage patients $(P>.05$; Fig 1$)$. Studies have shown significant increased serum levels of RANTES and MIP- $1 \beta$ in comparison to these levels in HIV-1-negative controls. ${ }^{12,28}$ High levels of circulating chemokines may be produced in the context of an inflammatory response to HIV-1 antigens and may also reflect an altered release from cellular sources other than $\mathrm{CD} 8^{+} \mathrm{T}$-lymphocytes and macrophages.

No significant difference in serum levels of MIP- $1 \alpha$, MIP- $1 \beta$, and RANTES has been found among the 4 clinical stages of HIV-1 infection for both HAARTnaïve and salvage groups $(P>.05$; Fig 1$)$, suggesting that serum levels of CC-chemokines did not play a major role in the control of disease stage. Our results were consistent with those of several investigations $^{24,25,38}$ implying that variations in serum levels of these CC-chemokines did not explain variations in the natural history of HIV-1 infection. Therefore, we and other investigators excluded serum CC-chemokine levels as biomarkers of HIV-1 disease stage.

To study serum CC-chemokine levels in relation to HIV-1 viral replication, we stratified patients into 3 categories according to baseline viral load for both HAART-naïve and salvage groups. The 3 viral-load categories were defined as less than or equal to $2.6 \mathrm{log}$ HIV-1 RNA copies/mL of blood, 2.6 to $5.0 \log$ HIV-1 RNA copies/mL of blood, and more than $5.0 \log$ HIV-1 RNA copies $/ \mathrm{mL}$ of blood. Our results indicated that patients with different viral loads had similar serum levels of all 3 CC-chemokines, in both HAART-naïve and salvage patients $(P>.05)$, suggesting a lack of correlation between serum CC-chemokines and HIV-1 replication (data not shown).

To explore the relationship between CC-chemokines and several immune and viral markers that are used to predict HIV-1 disease progression, we performed the Spearman rank-order correlation analysis using baseline values from 60 patients (Table III). MIP- $1 \alpha$ and MIP- $1 \beta$ levels were positively correlated, and MIP- $1 \alpha$ was positively correlated with
$\mathrm{CD}^{+}{ }^{+}$T-cell count. However, a correlation between MIP- $1 \alpha$ and $\mathrm{CD}^{+}{ }^{+}$T-cells in peripheral blood did not necessarily indicate that the serum level reflected the release of MIP- $1 \alpha$ from CD ${ }^{+}$T-cells. MIP- $1 \alpha$ may also be produced by $\mathrm{CD}^{+}{ }^{+}$T-cells and macrophages.

Lack of a correlation between CC-chemokines and viral load, especially for MIP- $1 \beta$, the only CC-chemokine that exclusively binds to CCR5, suggested a neutral role for CC-chemokines in affecting viral replication. In accordance with the results of other studies, ${ }^{28,39}$ our analyses suggested that CC-chemokines did not contribute to the control of viremia.

CC-chemokine levels during treatment. The role of $\mathrm{CC}$-chemokines as indicators of response to treatment is still debated. ${ }^{12,40,41}$ After the initiation of therapy in this study, decreases in HIV-1 RNA levels and increases in $\mathrm{CD} 4{ }^{+} \mathrm{T}$-cell counts were observed (data not shown). Longitudinal data indicated that serum MIP- $1 \alpha$ levels were markedly reduced after the initiation of treatment and remained low over the entire treatment period for both HAART-naïve and salvage patients $(P$ $<.05$; Fig 2). No significant difference, however, was detected for the MIP- $1 \beta$ level during treatment as compared with the baseline value $(P>.05 ;$ Fig 2$)$. Serum RANTES in HAART-naïve patients exhibited an early increase after the start of therapy $(P<.05)$, then recovered to baseline levels $(P>.05)$, whereas salvage patients maintained consistent levels of RANTES during the entire treatment course (Fig 2).

We further compared CC-chemokine levels in $\mathrm{VR}^{+} /$ $\mathrm{IR}^{+}$and $\mathrm{VR}^{-} / \mathrm{IR}^{-}$groups to test whether certain chemokines can be used as predictors of response to treatment. Our data indicated that responders and nonresponders in the HAART-naïve group had comparable serum levels of MIP- $1 \alpha$ and MIP- $1 \beta$. However, a temporary increase in RANTES after initiation of treatment was only observed in the naïve-nonresponder group (Fig 3). Among HAART-salvage patients, both responders and nonresponders showed similar trends in MIP- $1 \alpha$, MIP- $1 \beta$, and RANTES levels during treatment (Fig 3). The early decline in MIP- $1 \alpha$ after therapy 
A

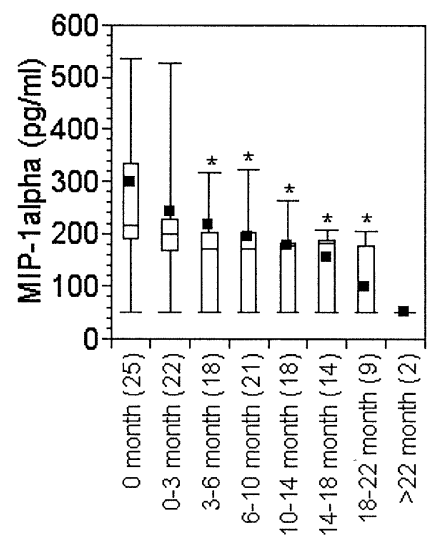

B

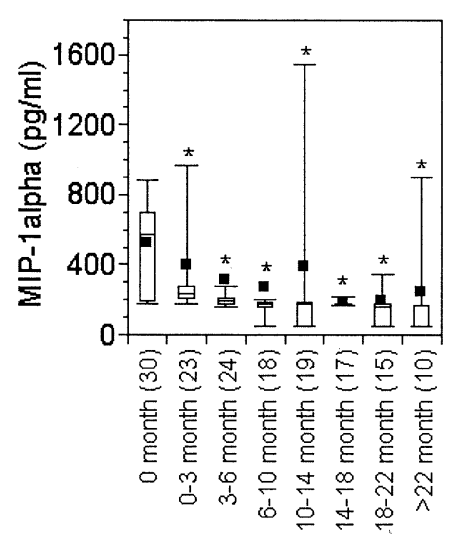

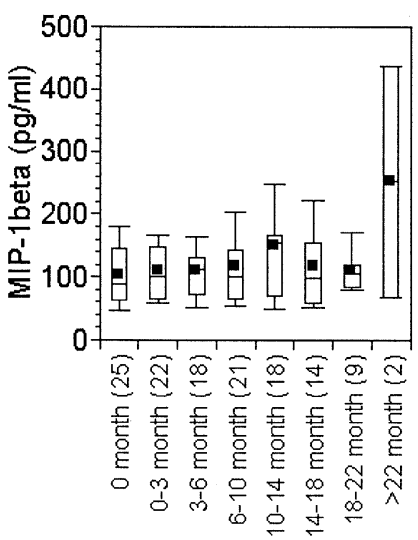
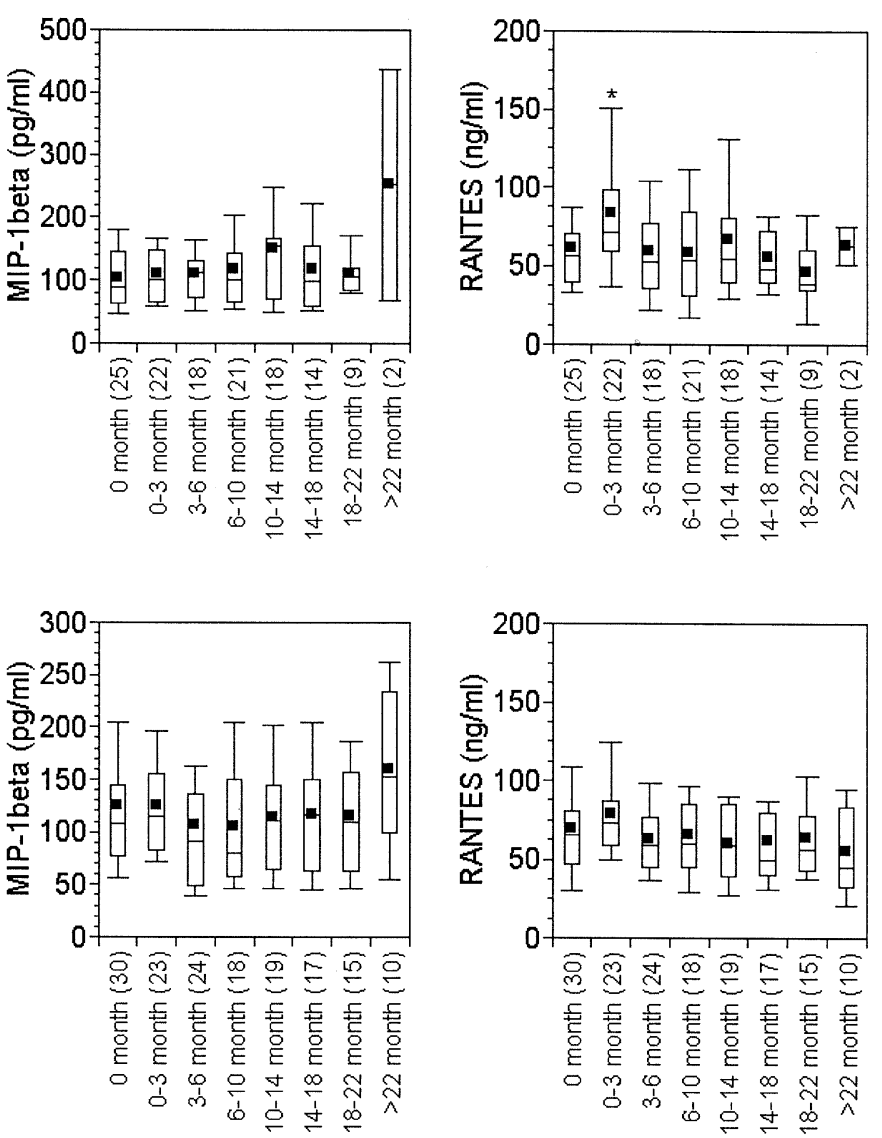

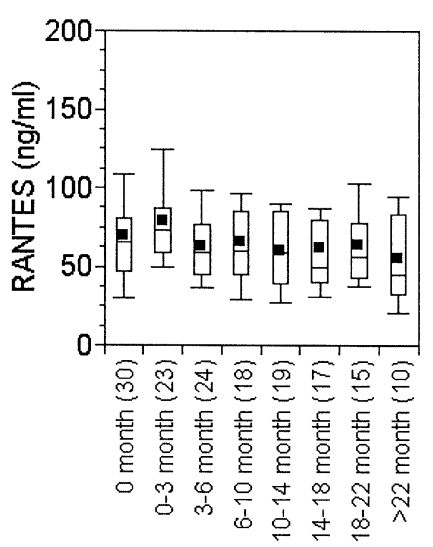

Fig 2. CC-chemokine kinetics during HAART. The lowest, second lowest, middle, second highest, and highest box points represent the 10 th percentile, 25 th percentile, median, 75th percentile, and 90th percentile, respectively. Means are represented by square symbols. The sample number is shown in parentheses for each group. ${ }^{*} P<.05$, baseline value vs each of the following treatment points (Wilcoxon's signed-rank test); absence of an asterisk indicates a $P$ value greater than .05 . A, HAART naïve patients; B, HAART-salvage patients.

may have resulted from either a direct therapeutic intervention or reduced activation of the immune response, but it cannot be used to predict response to treatment. Serum levels of CC-chemokines in discordant-responder groups $\left(\mathrm{VR}^{+} / \mathrm{IR}^{-}\right.$or $\left.\mathrm{VR}^{-} / \mathrm{IR}^{+}\right)$during treatment showed a trend between those of responder and nonresponder groups (data not shown).

CC-chemokine levels in patients not taking medication. Sequential specimens were available for 5 patients who did not meet indications for HAART. Each had a different CC-chemokines profile (Fig 4). This variability may be derived from the innate capacity to produce certain chemokines in response to immune stimuli or from residual HIV-1 replication occurring in lymphoid tissues. Patient 1004 exhibited pronounced declines in MIP- $1 \alpha$, MIP- $1 \beta$, and RANTES after entering the study. This patient was the only drug-naïve patient among the 5 off-medication patients and who had no opportunistic infection. This patient showed a decreased viral load, from 5.1 to $1.7 \mathrm{log}$, on entering the study, suggesting that this patient was an acute seroconverter who experienced a viral-load drop as the acute stage of HIV-1 infection ended. The patient's clinical history, combined with a preserved CD4 count and extremely high HIV load that markedly declined without the use of HAART, was consistent with an acute retroviral syndrome. The parallel changes of CCchemokines and viral load in this patient may have been related to an HIV-1-induced inflammatory response.

\section{DISCUSSION}

The role of CC-chemokines in the pathogenesis of HIV-1 infection is not well defined. This role is expected to be complicated; CC-chemokines have dichotomous effects on HIV-1 (eg, inhibition of viral entry vs enhancement of viral replication and induction of in- 

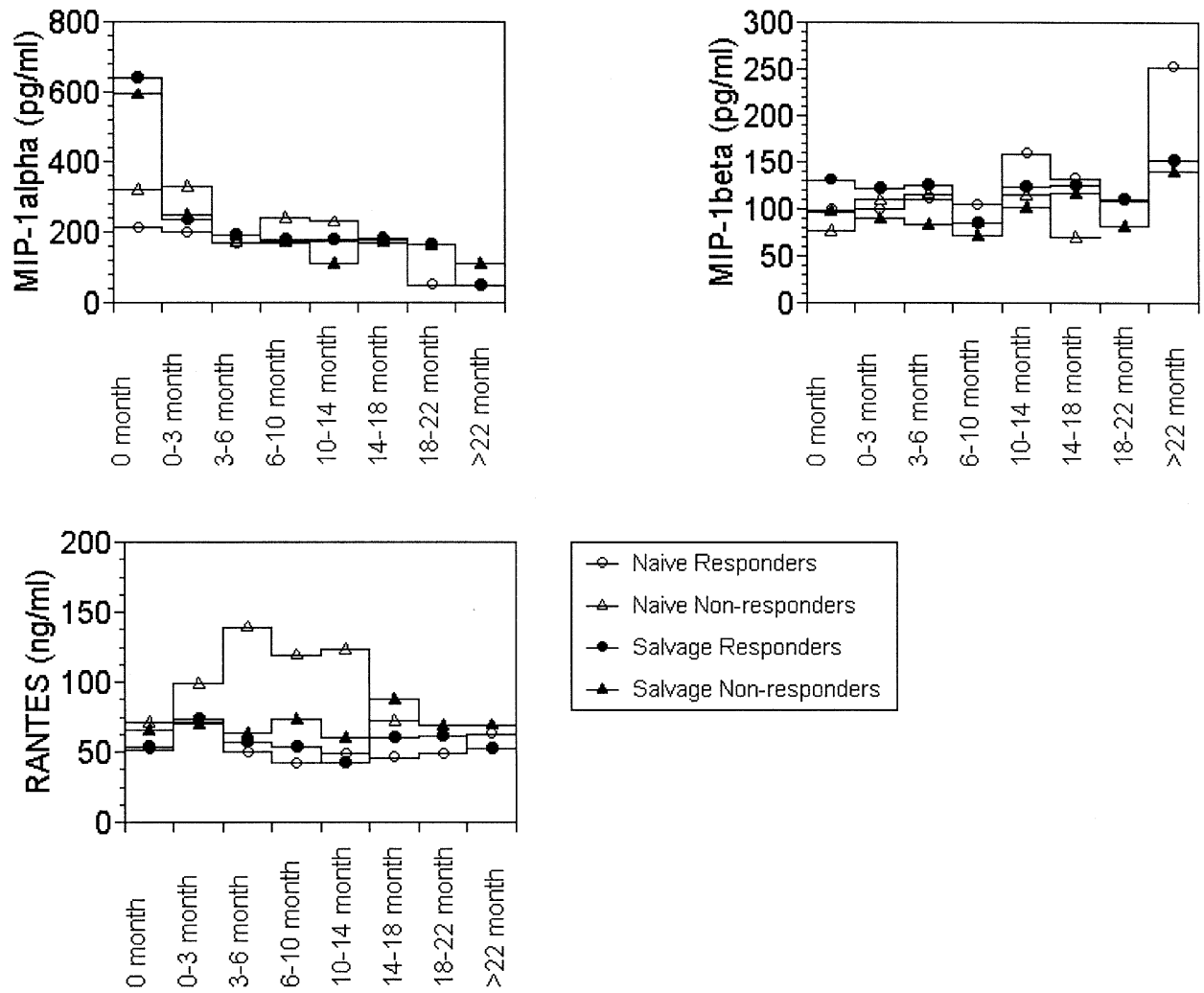

Fig 3. Relationship between CC-chemokines and responses to treatment. The medians of HAART-naïve responder and nonresponder and salvage responder and nonresponder groups are plotted for MIP- $1 \alpha$, MIP- $1 \beta$, and RANTES over the course of treatment.
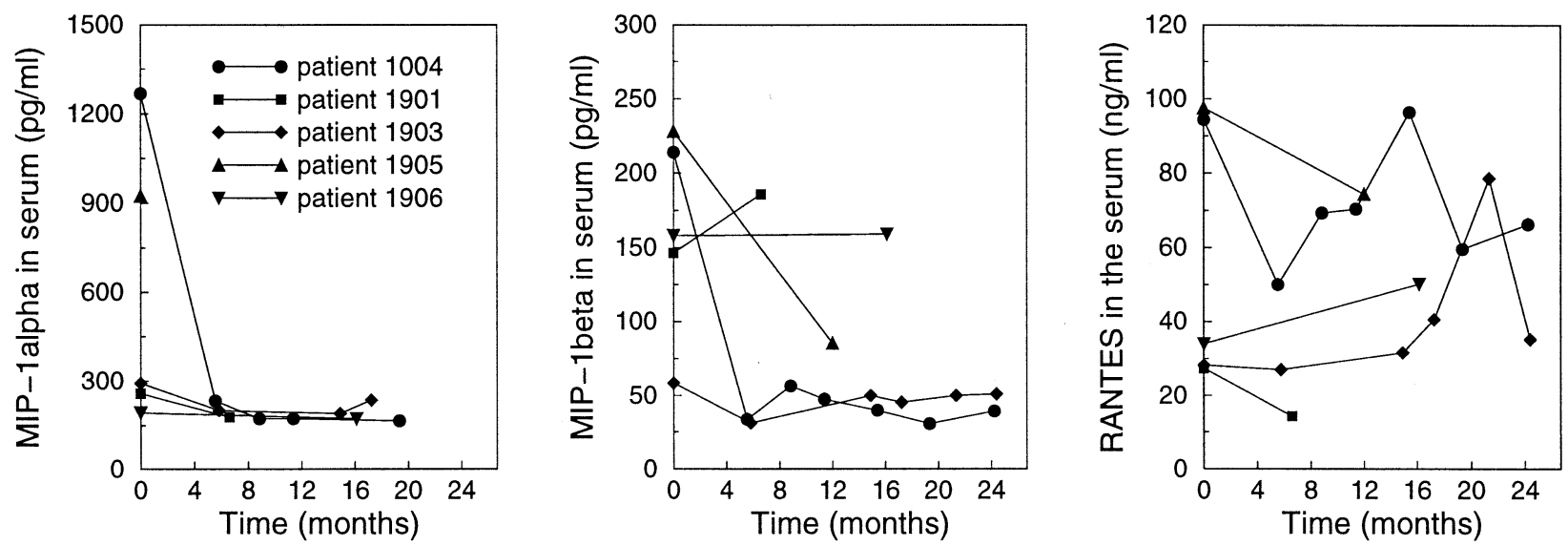

Fig 4. CC-chemokine levels over time in 5 patients who were not taking medication during the study.

flammatory response). A significant number of investigations measuring CC-chemokine production by $\mathrm{PB}$ MCs or purified $\mathrm{CD}^{+}$and $\mathrm{CD} 8^{+}$lymphocytes from HIV-1-infected individuals or serum CC-chemokines have not shown an inverse correlation between CC- chemokine levels and disease progression, ${ }^{24,25,38,42}$ yet in other investigations such inverse correlations have been noted. ${ }^{22,43-45}$

We detected serum levels of MIP- $1 \alpha$, MIP- $1 \beta$, and RANTES in $60 \mathrm{HIV}$-1-infected patients who were re- 
cruited to our study. Our analyses revealed that MIP- $1 \alpha$ and RANTES but not MIP- $1 \beta$ were significantly increased in these patients compared with healthy controls. Studies have shown that HIV-1 infection induces an increase in serum CC-chemokine levels, ${ }^{12,28,34,40,46,47}$ suggesting that exposure to HIV-1 results in activation of the chemokine network. ${ }^{24,38}$ With the identification of HIV-1 strains in these patients, it would be interesting to test whether increased CC-chemokine levels facilitate the selection of X4 strains. Our study also suggests that serum MIP- $1 \alpha$, MIP-1 $\beta$, and RANTES did not distinguish patients at different disease stages, in accordance with the findings of several investigations. ${ }^{24,25,38}$ No negative correlation anong 3 CC-chemokines and HIV-1 viral load was observed, consistent with the results of another 2 studies. ${ }^{28,39}$ We conclude that serum levels of CC-chemokines likely do not play a significant role in the control of viremia or in protection against disease progression.

The effects of HAART on the production of CCchemokines remain unclear. The purpose of this study was to determine whether serum chemokines are related to treatment response. After the initiation of treatment, we observed that MIP- $1 \alpha$ declined significantly among both HAART responders and nonresponders. This may have been a result of reduced immune-system activation or of direct therapeutic effects. In contrast, RANTES levels were increased in the HAART naïve group. This may have been a result of increased numbers of circulating activated $\mathrm{CD} 8^{+} \mathrm{T}$-cells, as well as natural-killer cells. ${ }^{16} \mathrm{We}$ also demonstrate that sex, age, race, and opportunistic infection had no effect on the levels of the 3 CC-chemokines in either HIV-1 infected patients or healthy controls.

The differences we observed in the 3 CC-chemokines may have been related to variations in affinity of chemokines to different receptors that we have not explored here. CC-chemokines may inhibit HIV-1 entry by way of their interactions with CCR5, but the signaling induced by MIP- $1 \alpha$ and RANTES binding to other receptors could enhance HIV-1 replication. Pretreatment of macrophages with MIP- $1 \alpha$, MIP- $1 \beta$, and RANTES augments HIV-1 infection, whereas these same chemokines have suppressive effects during and immediately after viral infection. ${ }^{20}$ RANTES enhances X4 HIV-1 replication in $\mathrm{CD} 4{ }^{+}$T-cells in a G-protein signaling-dependent manner. ${ }^{48}$ Therefore, examination of viral entry versus viral replication would help in evaluating the significance of CCchemokines in vivo.

The results of our study do not permit us to dismiss a role for MIP- $1 \alpha$, MIP- $1 \beta$, and RANTES in the control of viremia or protection against disease progression. It is possible that serum levels do not reflect local concentrations in sites of inflammation and HIV-1 replication. Therefore, additional studies in lymphoid tissues are needed to determine whether localized concentrations of CC-chemokines play a protective or harmful role in vivo. It may be that the potential of cells to secrete chemokines but not circulating chemokines directly regulates disease progression or viral load.

The exact cell types responsible for increased MIP- $1 \alpha$ and RANTES levels in this study have not been explored. HIV-1-infected macrophages and Tcells have both been shown to secrete the $3 \mathrm{CC}$-chemokines. ${ }^{49,50} \mathrm{We}$ found that $\mathrm{CD} 8^{+}$T-cell numbers were positively correlated with MIP- $1 \alpha$ but not with MIP- $1 \beta$ or RANTES. The lack of correlation between the number of $\mathrm{CD}^{+}{ }^{+}$T-cells and serum MIP- $1 \beta$ and RANTES levels does not exclude the possibility that $\mathrm{CD}^{+}{ }^{+} \mathrm{T}$-cells contribute to their release. The findings of 1 study suggest that MIP- $1 \beta$ is synthesized by a major population of $\mathrm{CD} 8^{+}$T-cells with a phenotype different from that of cytotoxic $\mathrm{T}$ lymphocytes effector cells, providing protective immunity against HIV-1. ${ }^{14}$ Macrophages respond to HIV-1 and its envelope protein (gp120) very rapidly by initiating synthesis of CC-chemokines. This is an important cellular response for regulating both viral infection and the recruitment of immune cells, favoring infection of these cells. ${ }^{51,52}$ Our findings suggest a lack of good correlation between serum CC-chemokines and HIV-1 disease stage or response to treatment. More studies will be necessary to precisely understand the action of CC-chemokines on HIV-1 replication and at all disease stages of virus/host interaction. More information will aid the proper evaluation of the significance of CC-chemokines in the pathogenesis of HIV-1 infection, their potential significance as an additional biomarker of disease progression, and in the development of new therapeutic agents.

We thank Dr Gary Huffnagle and Dr David Markovitz for their critical reading of our manuscript. We thank Dr Nick Luckas for his helpful discussions and Karyn Sutton, Margaret Catoe, Pamela Lincoln, and Holly Evanoff for excellent clinical and technical support.

\section{REFERENCES}

1. Deng H, Liu R, Ellmeier W, Choe S, Unutmaz D, Burkhart M, et al. Identification of a major co-receptor for primary isolates of HIV-1. Nature 1996;381:661-6.

2. Dragic T, Litwin V, Allaway GP, Martin SR, Huang Y, Nagashima KA, et al. HIV-1 entry into CD4+ cells is mediated by the chemokine receptor CC-CKR-5. Nature 1996;381:667-73.

3. Bleul CC, Farzan M, Choe H, Parolin C, Clark-Lewis I, Sodroski $\mathrm{J}$, et al. The lymphocyte chemoattractant SDF-1 is a ligand for LESTR/fusin and blocks HIV-1 entry. Nature 1996;382:829-33.

4. Oberlin E, Amara A, Bachelerie F, Bessia C, Virelizier JL, Arenzana-Seisdedos F, et al. The CXC chemokine SDF-1 is the ligand for LESTR/fusin and prevents infection by T-cell-lineadapted HIV-1. Nature 1996;382:833-5. 
5. Huang Y, Paxton WA, Wolinsky SM, Neumann AU, Zhang L, $\mathrm{He} \mathrm{T}$, et al. The role of a mutant CCR5 allele in HIV-1 transmission and disease progression. Nat Med 1996;2:1240-3.

6. Samson M, Libert F, Doranz BJ, Rucker J, Liesnard C, Farber $\mathrm{CM}$, et al. Resistance to HIV-1 infection in Caucasian individuals bearing mutant alleles of the CCR- 5 chemokine receptor gene. Nature 1996;382:722-5.

7. Stantchev TS, Broder CC. Human immunodeficiency virus type-1 and chemokines: beyond competition for common cellular receptors. Cytokine Growth Factor Rev 2001;12:219-43.

8. Cocchi F, DeVico AL, Garzino-Demo A, Arya SK, Gallo RC, Lusso P. Identification of RANTES, MIP-1 alpha, and MIP-1 beta as the major HIV-suppressive factors produced by CD8+ T cells. Science 1995;270:1811-5.

9. Kinter AL, Ostrowski M, Goletti D, Oliva A, Weissman D, Gantt $\mathrm{K}$, et al. HIV replication in CD4+ $\mathrm{T}$ cells of HIV-infected individuals is regulated by a balance between the viral suppressive effects of endogenous beta-chemokines and the viral inductive effects of other endogenous cytokines. Proc Natl Acad Sci U S A 1996;93:14076-81.

10. Scarlatti G, Tresoldi E, Bjorndal A, Fredriksson R, Colognesi C, Deng HK, et al. In vivo evolution of HIV-1 co-receptor usage and sensitivity to chemokine-mediated suppression. Nat Med 1997;3:1259-65.

11. Granelli-Piperno A, Moser B, Pope M, Chen D, Wei Y, Isdell F, et al. Efficient interaction of HIV-1 with purified dendritic cells via multiple chemokine coreceptors. J Exp Med 1996;184: 2433-8.

12. Aukrust P, Muller F, Froland SS. Circulating levels of RANTES in human immunodeficiency virus type 1 infection: effect of potent antiretroviral therapy. J Infect Dis 1998;177:1091-6.

13. Ferbas J, Giorgi JV, Amini S, Grovit-Ferbas K, Wiley DJ, Detels $\mathrm{R}$, et al. Antigen-specific production of RANTES, macrophage inflammatory protein (MIP)-1alpha, and MIP-1beta in vitro is a correlate of reduced human immunodeficiency virus burden in vivo. J Infect Dis 2000;182:1247-50.

14. Kamin-Lewis R, Abdelwahab SF, Trang C, Baker A, DeVico AL, Gallo RC, et al. Perforin-low memory CD8+ cells are the predominant $\mathrm{T}$ cells in normal humans that synthesize the beta -chemokine macrophage inßammatory protein-1beta. Proc Natl Acad Sci U S A 2001;98:9283-8.

15. Menten P, Wuyts A, Van Damme J. Macrophage inflammatory protein-1. Cytokine Growth Factor Rev 2002;13:455-81

16. Kottilil S, Chun TW, Moir S, Liu S, McLaughlin M, Hallahan $\mathrm{CW}$, et al. Innate immunity in human immunodeficiency virus infection: effect of viremia on natural killer cell function. J Infect Dis 2003;187:1038-45.

17. Amara A, Gall SL, Schwartz O, Salamero J, Montes M, Loetscher P, et al. HIV coreceptor downregulation as antiviral principle: SDF-1alpha-dependent internalization of the chemokine receptor CXCR4 contributes to inhibition of HIV replication. J Exp Med 1997;186:139-46.

18. Alkhatib G, Locati M, Kennedy PE, Murphy PM, Berger EA. HIV-1 coreceptor activity of CCR5 and its inhibition by chemokines: independence from $\mathrm{G}$ protein signaling and importance of coreceptor downmodulation. Virology 1997;234:340-8.

19. Simmons G, Reeves JD, Hibbitts S, Stine JT, Gray PW, Proudfoot AE, et al. Co-receptor use by HIV and inhibition of HIV infection by chemokine receptor ligands. Immunol Rev 2000; 177:112-26.

20. Kelly MD, Naif HM, Adams SL, Cunningham AL, Lloyd AR. Dichotomous effects of betachemokines on HIV replication in monocytes and monocyte-derived macrophages. J Immunol 1998;160:3091-5.
21. Moriuchi H, Moriuchi M, Combadiere C, Murphy PM, Fauci AS. CD8+ T-cell-derived soluble fac-tor(s), but not beta-chemokines RANTES, MIP-1 alpha, and MIP-1 beta, suppress HIV-1 replication in monocyte/macrophages. Proc Natl Acad Sci U S A 1996;93:15341-5.

22. Zanussi S, D'Andrea M, Simonelli C, Tirelli U, De Paoli P. Serum levels of RANTES and MIP-1 alpha in HIV-positive long-term survivors and progressor patients. AIDS 1996;10: 14312.

23. Polo S, Veglia F, Malnati MS, Gobbi C, Farci P, Raiteri R, et al. Longitudinal analysis of serum chemokine levels in the course of HIV-1 infection. AIDS 1999;13:447-54.

24. Krowka JF, Gesner ML, Ascher MS, Sheppard HW. Lack of associations of chemotactic cytokines with viral burden, disease progression, or lymphocyte subsets in HIV-infected individuals. Clin Immunol Immunopathol 1997;85:21-7.

25. McKenzie SW, Dallalio G, North M, Frame P, Means RT Jr. Serum chemokine levels in patients with non-progressing HIV infection. AIDS 1996;10:F29-33.

26. Cocchi F, DeVico AL, Yarchoan R, Redfield R, Cleghorn F, Blattner WA, et al. Higher macrophage inflammatory protein (MIP)-1alpha and MIP-1beta levels from CD8 $+\mathrm{T}$ cells are associated with asymptomatic HIV-1 infection. Proc Natl Acad Sci U S A 2000;97:13812-7.

27. Than S, Tumaliuan JA, Tamma S, Morales M, Bakshi S, Pahwa S. Chemokine pattern in relation to disease state in human immunodeficiency virus-infected children. AIDS Res Hum Retrovirus 1999;15:1279-85.

28. Muller P, Engelstadter M, Werner A, Braner J, Staszewski S, Miller V, et al. Increased serum and mRNA levels of RANTES associated with elevated levels of activated CD8+CD38+ T cells in HIV-1 infected individuals. Intervirology 1997;40:26370.

29. Sempowski GD, Haynes BF. Immune reconstitution in patients with HIV infection. Annu Rev Med 2002;53:269-84.

30. Kumar D, Parato K, Kumar A, Sun E, Cameron DW, Angel JB. Sustained suppression of plasma HIV RNA is associated with an increase in the production of mitogen-induced MIP-1alpha and MIP-1beta. AIDS Res Hum Retrovirus 1999;15:1073-7.

31. Carter LM, Peters BS, Ellis BA, Wolstencroft RA. Highly active antiretroviral therapy normalizes the potential for MIP-1alpha production in HIV infection. J Infect 2000;41:252-5.

32. Bisset LR, Rothen M, Joller-Jemelka HI, Dubs RW, Grob PJ, Opravil M. Change in circulating levels of the chemokines macrophage inflammatory proteins 1 alpha and 11 beta, RANTES, monocyte chemotactic protein-1 and interleukin-16 following treatment of severely immunodeficient HIV-infected individuals with indinavir. AIDS 1997;11:485-91.

33. Aleman S, Pehrson P, Sonnerborg A. Kinetics of beta-chemokine levels during anti-HIV therapy. Antivir Ther 1999;4:109-15.

34. Pierdominici M, Giovannetti A, Ensoli F, Mazzetta F, Marziali $\mathrm{M}$, De Cristofaro MR, et al. Changes in CCR5 and CXCR4 expression and beta-chemokine production in HIV-1-infected patients treated with highly active antiretroviral therapy. J Acquir Immune Defic Syndr 2002;29:122-31.

35. Dybul M, Fauci AS, Bartlett JG, Kaplan JE, Pau AK. Guidelines for using antiretroviral agents among HIV-infected adults and adolescents. Ann Intern Med 2002;137:381-433.

36. Chavan S, Bennuri B, Kharbanda M, Chandrasekaran A, Bakshi $\mathrm{S}$, Pahwa S. Evaluation of T cell receptor gene rearrangement excision circles after antiretroviral therapy in children infected with human immunodeficiency virus. J Infect Dis 2001;183: 1445-54.

37. 1993 revised classification system for HIV-1 infection and ex- 
panded surveillance case definition for AIDS among adolescents and adults. MMWR Morbid Mortal Wkly Rep 1992;41(RR-17): 1-19.

38. Vitale F, Bonura F, Perna AM, Ajello F, Romano N. Serum RANTES levels in HIV-positive individuals and in HIV-negative exposed health-care workers. Infection 1997;25:381-2.

39. Chen Y, Dampf D, Chen M, Kulka K, Volsky DJ, Saha K, et al. Dependence of CD8 + T-cell-mediated suppression of HIV type 1 on viral phenotypes and mediation of phenotype-dependent suppression by viral envelope gene and not by beta-chemokines. AIDS Res Hum Retrovirus 2000;16:117-24.

40. De Luca A, Giancola ML, Cingolani A, Ammassari A, Murri R, Antinori A. Circulating levels and ex vivo production of betachemokines, interferon gamma, and interleukin 2 in advanced human immunodeficiency virus type 1 infection: the effect of protease inhibitor therapy. AIDS Res Hum Retrovirus 2000;16: 835-43.

41. Fransen S, Copeland KF, Smieja M, Smaill F, Rosenthal KL. RANTES production by $\mathrm{T}$ cells and CD8-mediated inhibition of human immunodeficiency virus gene expression before initiation of potent antiretroviral therapy predict sustained suppression of viral replication. J Infect Dis 2000;181:505-12.

42. Greco G, Barker E, Levy JA. Differences in HIV replication in CD4+ lymphocytes are not related to beta-chemokine production. AIDS Res Hum Retrovirus 1998;14:1407-11.

43. Ullum H, Cozzi Lepri A, Victor J, Aladdin H, Phillips AN, Gerstoft $\mathbf{J}$, et al. Production of beta-chemokines in human immunodeficiency virus (HIV) infection: evidence that high levels of macrophage inflammatory protein-1beta are associated with a decreased risk of HIV disease progression. J Infect Dis 1998; 177:331-6.

44. Garzino-Demo A, Moss RB, Margolick JB, Cleghorn F, Sill A, Blattner WA, et al. Spontaneous and antigen-induced production of HIV-inhibitory beta-chemokines are associated with AIDSfree status. Proc Natl Acad Sci U S A 1999;96:11986-91.
45. Paxton WA, Neumann AU, Kang S, Deutch L, Brown RC, Koup RA, et al. RANTES production from CD4+ lymphocytes correlates with host genotype and rates of human immunodeficiency virus type 1 disease progression. J Infect Dis 2001;183:1678-81.

46. Jennes W, Sawadogo S, Koblavi-Deme S, Vuylsteke B, Maurice $\mathrm{C}$, Roels TH, et al. Positive association between beta-chemokine-producing $\mathrm{T}$ cells and HIV type 1 viral load in HIVinfected subjects in Abidjan, Cote d'Ivoire. AIDS Res Hum Retrovirus 2002;18:171-7.

47. Shieh B, Yan YP, Ko NY, Liau YE, Liu YC, Lin HH, et al. Detection of elevated serum beta-chemokine levels in seronegative Chinese individuals exposed to human immunodeficiency virus type 1. Clin Infect Dis 2001;33:273-9.

48. Kinter A, Catanzaro A, Monaco J, Ruiz M, Justement J, Moir S, et al. CC-chemokines enhance the replication of T-tropic strains of HIV-1 in CD4(+) T cells: role of signal transduction. Proc Natl Acad Sci U S A 1998;95:11880-5.

49. Canque B, Rosenzwajg M, Gey A, Tartour E, Fridman WH, Gluckman JC. Macrophage inflammatory protein-1alpha is induced by human immunodeficiency virus infection of monocytederived macrophages. Blood 1996;87:2011-9.

50. Annunziato F, Galli G, Nappi F, Cosmi L, Manetti R, Maggi E, et al. Limited expression of R5-tropic HIV-1 in CCR5-positive type 1-polarized $\mathrm{T}$ cells explained by their ability to produce RANTES, MIP1alpha, and MIP-1beta. Blood 2000;95:1167-74.

51. Choe W, Volsky DJ, Potash MJ. Induction of rapid and extensive beta-chemokine synthesis in macrophages by human immunodeficiency virus type 1 and gp120, independently of their coreceptor phenotype. J Virol 2001;75:1073845.

52. Fantuzzi L, Canini I, Belardelli F, Gessani S. HIV-1 gp120 stimulates the production of beta-chemokines in human peripheral blood monocytes through a CD4-independent mechanism. J Immunol 2001;166:53817. 